\title{
Review of The Systemic Concept of Intellectual Capital and Determining its Practical Implications in Education
}

\author{
Tahereh Alsadat Tabatabaee ${ }^{1}$, Alireza Chenari ${ }^{2 *}$, Soghra Afkaneh ${ }^{3}$ \\ 1. PhD Student in Educational Management, Department of Educational Management, Rodehen Branch, Islamic Azad \\ University, Rodehen, Iran. \\ 2. Assistant Professor, Department of Educational Management, Rodehen Branch, Islamic Azad University, Rodehen, Iran. \\ 3. Assistant Professor, Department of Educational Management, Rodehen Branch, Islamic Azad University, Rodehen, Iran. \\ * Corresponding author's Email: a.chenari@yahoo.com
}

\begin{abstract}
Intellectual capital has been used as a formal, acquired and citation source in order to create spiritual assets, expertise and experience to create and develop knowledge. Intellectual capital is the knowledge available in organizations, which includes three types of the human capital including knowledge, skills and talent, the structural level including the database, organizational process and technology, and relational capital including organization's relationship with customers. Education is a place that plays an important role in the development of schools and training of staff and students, and is the most important place for value creation in various human, structural and relational fields. Indeed, education plays an important role in strategy and creating intellectual backgrounds and creating a specific input of people, structure and frameworks and connections that exist in the structure of this sector will increase the use of creativity and innovation in education. Due to the growing importance of intellectual capital and systemic model, management of this issue has become one of the routine concerns of all organizations, especially education. In this article, the concept of intellectual capital is examined and its practical implications in education are discussed.
\end{abstract}

Keywords: Intellectual capital, education, structural capital, relational capital, human capital

\section{Introduction}

With the development of values in all knowledge-based organizations, there has been a great interest in the field of intellectual capital, so researchers have tried to define and measure the category of intellectual capital, which was immeasurable in the 1990s (Qalavandi, Pashazadeh, Sultanzadeh, \& Saghafi, 2011). Currently, the most valuable economic resource is wealth, creation and management of intangible assets, commonly referred to as knowledge or intellectual capital. Given that the main purpose of educational centers is the production and dissemination of knowledge and research, knowledge management and intellectual capital approaches are of great importance to it. The importance of intangible assets for value creation in all organizations is increasing so that a significant share of value created in organizations is due to the management of intellectual capital (Dadashi Khass \& Babaei Nivlooei, 2014).

We are moving towards an economy in which intellectual capital and investment are an important factor in creating value in organizations (Zambon, Chatzkel, Sánchez, \& Elena, 2006). Intellectual capital has been used as a formal, acquired and citation source in order to create spiritual assets, expertise and experience to create and develop knowledge. Intellectual capital is the knowledge that exists in 
organizations, which includes three individual levels including knowledge, skills and aptitude, and the structural level including the database, organizational process and technology (Haanes \& Lowendahl, 1997). Intellectual capital is a set of knowledge-based assets that is specific to an organization and is considered one of its characteristics that, through value to the key stakeholders of the organization, significantly increase the competitive advantage of the organization (Marr \& Moustaghfir, 2005).

One of the most important indicators of sustainable development in countries is the growth of intellectual capital in society, the loss of this capital poses a threat to the growth and development of that country. Attracting the intellectual capital of other countries to developed countries is an opportunity to meet the needs of that country. Due to the importance of intellectual capital in countries over time, countries increase the desire to attract specialized forces and intellectual capital (Alburo, 2003). On the other hand, intellectual capital is a kind of intangible resources and defined activities that allow an organization to become a powerful value-creating system with a volume of raw materials, human and financial resources (Khalique, Nassir Shaari, \& Isa, 2011).

Intellectual capital is the ability of an organization to raise the level of literacy. This capability allows organizations, including education, to create and introduce new products and services, design new practices in their business, or define new organizational forms for themselves. The Education organization is one of the most important, effective and extensive organizations that are responsible for the formal education and training of people in the community. Therefore, the necessity of continuity and survival of any society is the set of beliefs, values, behaviors, tendencies and knowledge and skills be passed on to new generations. Sociologically, education is considered as a social institution and social organization. Education, like other social phenomena, has various functions. Also, the transfer of culture, socialization, social supervision, social unity, personal upbringing and development, political upbringing and training of skilled manpower are important functions of education (Ahmadi, Hatamizadeh, \& Hosseini, 2016).

Education plays an important role in the development of schools and the training of staff and students, and is the most important place for value creation in various human, structural and relational fields. Therefore, considering the important functions of education and inputs such as employees and managers as sources of intellectual capital and creativity, it must have correct and basic output and feedback.

Due to the growing importance of intellectual capital and systemic model, management of this issue has become one of the routine concerns of all organizations, especially education. In this article, the concept of intellectual capital is examined and its practical implications in education are discussed. Based on this, the most important studies in this field have been examined.

\section{Literature Review}

Zahedi et al. (2019) tried in their research to identify and prioritize the dimensions and components of intellectual capital in technology-based organizations, using interviews with experts, extracting the components of intellectual capital and then prioritizing using fuzzy hierarchical analysis technique. The results showed that the intellectual capital of technology-based organizations consisted of three capitals: 
human, structural and social. The results of component prioritization showed that the human capital component is the most important in these organizations.

Navid Adham and Shafizadeh (2019) studied the relationship between strategic thinking and intellectual capital with a tendency to organizational innovation among managers and experts of the General Directorate of Education in Tehran. In this study, the statistical population of the study included all managers and experts of the Education Department of Tehran province and its affiliated areas. The results showed that strategic thinking compared to intellectual capital, has a greater impact on the tendency to organizational innovation among managers of education departments in Tehran.

Bakhtiari and Mosa Khany (2015) conducted a study entitled "Presenting a structural model of factors affecting the growth of intellectual capital among faculty members of medical universities. In this study, data collection was performed using a questionnaire and 260 members of the community. The results showed the perception of organizational support, quality of work life, organizational commitment, job satisfaction, job characteristics, professionalism, personal characteristics, perfectionism, trade unions and faculty members, creating opportunities for growth and professional development, supporting innovative projects, system of salaries and rewards and budget allocation are effective on intellectual capital.

Tafteh (2018) in a study examined the relationship between spiritual intelligence and perception of organizational climate with the intellectual capital of the staff of the Islamic Azad University of Marvdasht. Required data for the research were collected using a questionnaire from 115 faculty members of university. The results indicated that there is a positive and significant relationship between spiritual intelligence and intellectual capital. Also, results indicated that the dimensions of perception of organizational climate are related to employees' intellectual capital. Furthermore, among the predictor variables, the perception variable of organizational climate can be a predictor of intellectual capital variable.

Darvishi and Ziaee Bideh (2018) in a study examined the role of intellectual capital in the development of various organizational innovations with emphasis on the environmental approach. The statistical population of this study was all companies active in the oil, gas and petrochemical industry of Khuzestan province. The results showed that intellectual capital can strengthen environmental innovation (including managerial innovation, product innovation, technological innovation and green process innovation) in the organization.

Bontis, Wu, Chen, Cheng, and Hwang (2005) in a study indicated that firms' intellectual capital has a positive effect on market value and commercial performance, and may be an indicator for future financial performance. Also, the researchers found that investors may place different value on the three components of value creation efficiency (physical capital, human capital, and structural capital).

Yong, Yusliza, Ramayah, and Fawehinmi (2019) conducted a study entitled 'The relationship between intellectual capital and human resources'. The results of this study showed that human capital and relational capital affect human resource management. Iqbal, Latif, Marimon, Sahibzada, and Hussain (2019) in a study entitled 'From knowledge management to organizational performance: modeling the 
mediating role of intellectual capital in higher education' showed that the interaction of knowledge management using intellectual capital increases innovation in the organization. The results also showed how managers of higher education institutions can promote innovation in intellectual capital and in turn increase the performance of intellectual capital in organizations.

(Silva \& Ferreira, 2019) did a study entitled 'Presenting a model of indicators of intellectual capital for universities and analyzing them in the management reports of Brazilian public universities. The results showed that intellectual capital in higher education institutions can be one of the key elements in promoting sustainability in universities.

Bornemann and Wiedenhofer (2014), in a study applied the concept of intellectual capital to assess intangible resources as crucial for the quality of educational processes. The results indicated that prioritizing scarce resources and systematically monitoring intangible assets in public as well as privately management educational intuitions contributes to economic improvement and better accomplishment of strategic objectives.

Some studies examined the intellectual capital in higher education. For example, Pedro, Leitão, and Alves (2019) presented an innovative operational proposal for measuring the intellectual capital (IC) of higher education institutions (HEIs) through a strategic prospective lens of analysis. The results indicated how human capital, structural capital and relational capital make up the core components and provide a fairly diversified list of the measurement indicators for the operational evaluation of the IC of HEIs. In line with studies conducted in higher education, Shehzad, Fareed, Zulfiqar, Shahzad, and Latif (2014) explored the role and relationship of intellectual capital and its three components on the performance and efficient working of universities in Pakistan. The researchers studied three components of intellectual capital such as human capital, structural capital and relational capital as independent variables and institution's performance as dependent variable. A structured questionnaire was adopted from the past research studies and 800 responses were collected from various public and private university students in Pakistan. Reliability analysis was conducted to check the reliability of constructs and Pearson's correlation was applied to explore the relationship of three components of IC on institution performance. The results indicated that all the three components had a significant relationship with performance but among the three components, the relation of human capital was more prominent.

Overall, a review of the studies on intellectual capital in education and higher education showed that the three components of human capital, structural capital and relational capital are three components that most researchers agree on. In the discussion and conclusion section, these three components have been discussed more comprehensively

\section{Discussion and Conclusion}

Organizations cannot succeed only by relying on their traditional assets and capital in the new age, which is associated with changes and dynamics of the environment. Today, the emphasis of leading organizations is on identifying new assets and properties that can rely on these assets and manage it to keep pace with changes in the environment. One of these assets is the intellectual capital discussed in 
this article. Intellectual capital is reflected in customers, processes, information, brand, human resources and systems of the organization and plays an increasing role in creating competitive advantages.

As stated in this article, numerous typologies are proposed by different investigators in the literature. Among these, the three-dimensional classification of intellectual capital, that includes human capital, structural capital, and relational capital has attained a certain degree of agreement among researchers (Kavida \& Sivakoumar, 2009b; Roos \& Roos, 1997). Also, according to the research background, many studies have been conducted on the effect of intellectual capital on other organizational variables. The results of research on intellectual capital can be used in the field of education, especially in the field of management.

Human capital is the major component in the intellectual capital development process (Yang \& Lin, 2009). It is inborn in people and therefore cannot be directly owned by an organization (Edvinsson \& Malone, 1997). Human capital designates what employees bring into the value adding processes, and encompasses professional capability, employee enthusiasm, and leadership capability (Halim, 2010). Kavida and Sivakoumar (2009a) considered human capital as a summation of employees' skill, education, experience, capabilities and attitude about life and business. A number of capabilities such as learning and instruction, experience and knowledge, creativity, staff attitude as well as recruitment and education plays a significant role in the development of human capital (Lings \& Greenley, 2005; Sharabati, Jawad, \& Bontis, 2010). For instance, in educational organization, educated, experienced, trained, creative, and motivated managers and teachers can work more efficiently and thereby result in the establishment of organizational capital.

The second component of intellectual capital is relational capital which has been enumerated in previous studies. Relational capital results from organization's relationship with customers, partners, shareholders, and other stakeholders that are critical to the organizational performance (Bontis, 2001). Shih, Chang, and Lin (2010) considered relational capital as the interaction between organizations, suppliers, contractors, customers and other associated partners. Low (2000) elucidated relational capital as the stream of knowledge from an organization to outside situation. The capabilities such as customer relation as well as customer loyalty and trust play important role in the development of relational capital (Isaac, Herremans, \& Kline, 2010). For instance, higher the degree of students' loyalty and families trust, better will be the relationship with them, which consequently enriches organizational value.

Structural capital denotes to the mechanism and structure of an organization that helps to support employees for best intellectual performance (Bollen, Vergauwen, \& Schnieders, 2005). Edvinsson and Malone (1997) emphasized that structural capital involved of non-human store houses of knowledge in an organization which are entrenched in systems, databases, and programs. Further, Bontis, Crossan, and Hulland (2002) commented that an individual in an organization could never grasp the fullest potential of its systems if its procedures were poor. The structural capital is the consequence that is prolonged from systems and programs, IT, culture, and restoration and development which significantly donate to the development of structural capital scale (Choudhury, 2010). For example, well-defined 
structures, standards, systems, and information technology improve the efficiency of teachers and can create better students' relations, thereby enhancing the organizational value.

In general, the concept of intellectual capital is one of the structures that should be considered in any organization, especially in education. The results of previous studies showed that similar to other organizations, in education, three components of human, structural and relational intellectual capital have an effective role in increasing the value of the organization. Considering that human capital in education can be more effective in increasing organizational value than other organizations, it is suggested that education managers plan for its growth and development.

Conflict of interest: The authors stated no conflict of interest in the study.

Financial sponsor: The authors acknowledge that they have not received any financial support for all stages of the study, writing and publication of the paper.

\section{References}

Ahmadi, M., Hatamizadeh, N., \& Hosseini, M. (2016). Identify and classify concepts and components of intellectual capital in the organizations. Journal of Health Promotion Management, 5(3), 15-27.

Alburo, F. A. (2003). The Role of PillS and Its Contributions to Research and Policymaking in the Philippines. Philippine Journal of Development, 3(2), 149-172.

Bakhtiari, N., \& Mosa Khany, M. (2015). Investigating the Relationship between intellectual capital and Research Performance among Academic board members of Shahid Rajaee Teacher Training University. Technology of Education Journal (TEJ), 10(1), 75-84. doi:10.22061/tej.2015.440

Bollen, L., Vergauwen, P., \& Schnieders, S. (2005). Linking intellectual capital and intellectual property to company performance. Management Decision, 43(9), 1161-1185.

Bontis, N. (2001). Assessing knowledge assets: a review of the models used to measure intellectual capital. International journal of management reviews, 3(1), 41-60.

Bontis, N., Crossan, M. M., \& Hulland, J. (2002). Managing an organizational learning system by aligning stocks and flows. Journal of management studies, 39(4), 437-469.

Bontis, N., Wu, S., Chen, M. C., Cheng, S. J., \& Hwang, Y. (2005). An empirical investigation of the relationship between intellectual capital and firms' market value and financial performance. Journal of intellectual capital, 6(2), 159-176.

Bornemann, M., \& Wiedenhofer, R. (2014). Intellectual capital in education: a value chain perspective. Journal of intellectual capital, 15(3), 451-470.

Choudhury, J. (2010). Performance impact of intellectual capital: a study of Indian IT sector. International journal of business and management, 5(9), 72-80. 
Dadashi Khass, E., \& Babaei Nivlooei, F. (2014). The Survey of the Effect of Intellectual Capital Management on Managers Strategic Decision Making in Companies of Industrial District. Journal of Development \& Evolution Mnagement, 1393(17), 17-26.

Darvishi, M., \& Ziaee Bideh, A. (2018). Investigating the role of green intellectual capital in developing different type of organizational innovation with regard to the environmental aspect(Study in oil, gas and petrochemical in Khuzestan province). Human Resource Management in Oil Industry, 9(34), 145-170.

Edvinsson, L., \& Malone, M. (1997). Realizing your company's true value by finding its hidden brain power. New York: Harper Business.

Haanes, K., \& Lowendahl, B. (1997). The unit of activity: towards an alternative to the theories of the firm. Strategy, structure and style, 2(4), 201-218.

Halim, S. (2010). Statistical analysis on the intellectual capital statement. Journal of intellectual capital, $11(1), 61-73$.

Iqbal, A., Latif, F., Marimon, F., Sahibzada, U. F., \& Hussain, S. (2019). From knowledge management to organizational performance. Journal of Enterprise Information Management, 32(1), 36-59.

Isaac, R. G., Herremans, I. M., \& Kline, T. J. (2010). Intellectual capital management enablers: a structural equation modeling analysis. Journal of Business Ethics, 93(3), 373-391.

Kavida, V., \& Sivakoumar, N. (2009a). Intellectual Capital: A Strategic Management Perspective. IUP Journal of Knowledge Management, 7(6), 55-69.

Kavida, V., \& Sivakoumar, N. (2009b). Intellectual Capital: A Strategic Management Perspective. IUP Journal of Knowledge Management, 7(6), 55-69.

Khalique, M., Nassir Shaari, J. A., \& Isa, A. H. B. M. (2011). Intellectual capital and its major components. International Journal of Current Research, 3(6), 343-347.

Lings, I. N., \& Greenley, G. E. (2005). Measuring internal market orientation. Journal of service research, 7(3), 290-305.

Low, J. (2000). The value creation index. Journal of intellectual capital, 1(3), 252-262.

Marr, B., \& Moustaghfir, K. (2005). Defining intellectual capital: a three-dimensional approach. Management Decision, 43(9), 1114-1128.

Navid Adham, M., \& Shafizadeh, H. (2019). Investigating the Relationship between Strategic Thinking and Intellectual Capital with an Attitude Toward Organizational Innovation among Managers and Experts in Tehran Education Areas. Technology of Education Journal (TEJ), 13(4), 881-890. doi:10.22061/jte.2019.5065.2163

Pedro, E., Leitão, J., \& Alves, H. (2019). The intellectual capital of higher education institutions. Journal of intellectual capital, 20(3), 355-381.

Qalavandi, H., Pashazadeh, Y., Sultanzadeh, V., \& Saghafi, P. (2011). Determining the relationship between organizational learning components based on the dimensions of intellectual capital among faculty members of Urmia University. Paper presented at the The First National Conference on Systemic Approach, Shiraz. https://civilica.com/doc/144046/ 
Roos, G., \& Roos, J. (1997). Measuring your company's intellectual performance. Long range planning, $30(3), 413-426$.

Sharabati, A. A. A., Jawad, S. N., \& Bontis, N. (2010). Intellectual capital and business performance in the pharmaceutical sector of Jordan. Management Decision, 48(1), 105-131.

Shehzad, U., Fareed, Z., Zulfiqar, B., Shahzad, F., \& Latif, H. S. (2014). The impact of intellectual capital on the performance of universities. European Journal of Contemporary Education, 10(4), 273-280.

Shih, K. H., Chang, C. J., \& Lin, B. (2010). Assessing knowledge creation and intellectual capital in banking industry. Journal of intellectual capital, 11(1), 74-89.

Silva, T. M., \& Ferreira, A. (2019). Intellectual Capital Sustainability in Brazilian Public Higher Education. In Intellectual Capital Management as a Driver of Sustainability (pp. 177-203): Springer.

Tafteh, M. (2018). The relationship between Spiritual Intelligence and Organizational Atmosphere with Human Capital Perception in Personnel of Islamic Azad University ,Marvdasht Branch. Journal of New Approaches in Educational Administration, 9(34), 129-150.

Yang, C.-C., \& Lin, C. Y.-Y. (2009). Does intellectual capital mediate the relationship between HRM and organizational performance? Perspective of a healthcare industry in Taiwan. The International Journal of Human Resource Management, 20(9), 1965-1984.

Yong, J. Y., Yusliza, M., Ramayah, T., \& Fawehinmi, O. (2019). Nexus between green intellectual capital and green human resource management. Journal of cleaner production, 215, 364-374.

Zambon, S., Chatzkel, J., Sánchez, M. P., \& Elena, S. (2006). Intellectual capital in universities. Journal of intellectual capital, 7(4), 529-548. doi:10.1108/14691930610709158 